\title{
Natural Resources: the Demands of Equality
}

Chris Armstrong, University of Southampton

\section{Egalitarianism and Natural Resources}

Egalitarians have long been interested in the benefits and burdens flowing from natural resources, and understandably so. Some natural resources (such as water) are essential ingredients of any human life; others (such as diamonds) are not essential at all but are nevertheless hugely valuable. Nature, though, appears to have favoured some of its children over others. Some of us have ready access to valuable resources, whilst others have to struggle even to obtain the basic essentials. Meanwhile people, lest we credit (or blame) nature for too much, have also done their fair share to build upon that unequal foundation. Individuals around the world are forcibly excluded from accessing many resources by border guards, police forces, and the security personnel of major corporations. Nature, likewise, can hardly be blamed for the ways in which access to resources frequently tracks class, gender and ethnicity. Either way, egalitarians have frequently been convinced that highly uneven shares of natural resources' benefits and burdens represent serious injustices.

Indeed egalitarians have often suggested that natural resource inequalities are especially egregious - and especially suitable for correction - given the 'arbitrariness' of the way in which resources have come to be distributed. But just what should they demand by way of correction? What would constitute an appropriately egalitarian distribution of benefits and burdens? One very well-known answer to that question 
holds that we are each, individually, entitled to an equal share of benefits. To be clear the claim, typically, is not that we are entitled to equal shares of natural resources themselves. Indeed it is hard to see why anyone would be attracted to an equal division of resources per se, or indeed how we would measure such shares (would the principle suggest an equal share of the world's natural resources divided by weight? By volume? By type, and then by volume?). Rather, the claim is typically that whatever the benefits and burdens flowing from the world's resources, we are entitled to an equal share of them. Given that natural resources are not created by anyone, but are rather a gift of 'God' or of 'nature,' the thought goes, then an equal distribution of that 'common treasury' is, in a sense, a birth-right.

It is this claim that the present paper challenges. It shows, in fact, that egalitarians ought to adopt an alternative, more complex position on natural resources, and shows how that more complex view has important implications for debates on, for instance, resource appropriation and intergenerational justice. But before proceeding further, we need to clarify a few issues which the paper does not seek to resolve. First, it stays on the surface of debates about just what precisely constitutes a natural resource. I do address that question in more depth elsewhere, ${ }^{1}$ but to keep this discussion manageable I adopt a general view which is common to both many discussions of natural resource justice and to international law: natural resources are a category which includes objects not created by human beings. ${ }^{2}$ This could then include, somewhat narrowly, familiar items such as oil, diamonds, or water. More broadly, it could also include items such as wild animals and plants, and, on some accounts, land itself. The argument that follows, if it is a good one, ought to count against equal benefits whether the set of 'natural resources' is construed relatively narrowly or relatively broadly. The point is that however we define natural resources 
- unless we expand that category to include all of the goods relevant to justice, in which case it fails to single out anything distinctive - the argument for equal benefits fails. Second, I take it that an account of natural resource justice should be interested in both the benefits and the burdens arising from natural resources. Often discussion has appeared to focus on benefits: on, for instance, distributing the economic value of natural resources. But burdens matter too and if, for instance, we hold that no-one ought to be disadvantaged through uneven access to the benefits arising from natural resources, the same conclusion should follow for burdens. But I do not attempt to adjudicate the question of what metric we might use to judge whether the benefits and burdens enjoyed by any two individuals are equal. It might be that equal benefits should be gauged by some measure of the welfare or capabilities that natural resources support, or by shares of their monetary value, or by establishing what individuals would bid for them in a hypothetical auction, for example. In what follows I use 'equal benefits' as a shorthand for an equal division of the benefits and burdens flowing from all of the world's natural resources however the particular views under discussion propose to measure those benefits and burdens against one another. Third, as should be clear, the paper addresses itself to egalitarians and not to sufficientarians or prioritarians about justice. Addressing those other views would be worthwhile but would make the discussion unmanageable. In any case it is egalitarians who have suggested that justice requires equal shares of natural resource benefits, and the contribution of this paper is to show that such a view is mistaken, that it ought to be rejected in favour of a more complex view, and to spell out some of the implications for egalitarian justice.

In section II of this paper I briefly demonstrate the wide support which the idea of equal shares of benefits has commanded. Section III then examines, but rejects, 
four arguments in favour of equal natural resource benefits, the first two of which focus on the general normative distinctiveness of natural resources, whereas the final two properly raise concerns of non-ideal theory. Working through and individually refuting the various arguments is necessary to show that a very prominent egalitarian view on natural resources is mistaken. Instead global egalitarians have compelling reasons to prefer an alternative set of principles to govern the distribution of any benefits, which I elucidate in section IV. The first secures for each of us access to the resources necessary for meeting our basic rights. The second favours equal benefits just in case we have good reason to fear that unequal access to natural resources specifically and perniciously sustains other inequalities - such as inequalities in status organised according to gender or ethnicity - and where equal benefits promise to be particularly efficacious in tackling those other inequalities. But whilst this will often be the case it is not always so, and hence the argument for equal shares does not strongly generalise. Our third principle endorses not equal resource benefits but equalizing shares of benefits. We should use the proceeds of any global tax on natural resources, that is, to ameliorate inequalities not specifically in natural resource holdings, but rather to address inequalities across the range of advantages and disadvantages relevant to egalitarian justice. That implies that we ought to carefully target the proceeds of any resource taxes: doing the most good, from a broad egalitarian point of view, is likely to require that we disburse natural resource benefits highly unevenly.

The implications of this account are manifold. One surprising finding is precisely that a principle which has enjoyed the support of a great many important philosophers of justice turns out to be indefensible. But the account has important implications for discussions of the appropriation of natural resources, and in turn for 
concrete issues such as the right to emit carbon dioxide. In section V I show that what is a very familiar 'narrow' egalitarian proviso applying to appropriation of scarce resources, for instance, ought to be rejected in favour of a 'broad' proviso on appropriation. In section VI, finally, I briefly sketch the implications of the view for intergenerational justice.

\section{Support for Equal Benefits}

In the seventeenth century, the idea that the earth was (at least originally) given to humankind in common - with no-one having any special claims to it - provided a shared starting-point for Hugo Grotius, Thomas Hobbes, John Locke, and Samuel von Pufendorf, among others. But the widespread view that the natural resources of the world formed a 'common treasury' was only turned by to radical ends by some, as by the English radical Gerrard Winstanley who declared in 1649 that 'the Earth, with all her fruits of Corn, Cattle, and such like, was made to be a common Store-house of Livelihood to all Mankind, friend, and foe without exception,' and used that to justify a campaign of (peaceful) insurrection against the landed elite of the time. ${ }^{3}$ But for Locke, famously, private property could, subject to certain provisos, justly be removed from the common stock. Only where those provisos were violated did it make sense to talk of compensation for appropriation. ${ }^{4}$ Others argued that our common inheritance of the earth's resources produced an argument for an equal share of benefits, perhaps taking the form of an equal basic income. Thus Thomas Paine claimed that each of us is 'a joint life proprietor, with the rest, in the property of the soil, and in all its natural productions, vegetable and animal.' He argued, as a result, for a right to a basic capital stake for all, and a basic income for people over fifty 
years of age 'in lieu of the natural inheritance, which, as a right, belongs to every man. ${ }^{5}$ Eighty years later Henry George argued for a tax on the unimproved value of land and its resources, with the proceeds being shared equally between all. ${ }^{6}$

In more recent debates about global justice, a version of the same idea has been reprised by Charles Beitz, who argued that even if we lived in a world of selfcontained societies, the highly unequal distribution of natural resources between societies should be troubling from the point of view of justice. Rather than allowing societies to suffer (or prosper) as a result of this uneven distribution we should instead embrace a principle which would see the value of natural resources redistributed to at least mitigate the inequalities emanating from it. ${ }^{7}$ Beitz was in the end reticent about the role such a principle should play in a fully developed account of global justice, and instead embraced a global difference principle the implications of which for resources would likely be quite different. ${ }^{8}$ But others have been less reticent. Brian Barry argued for a principle which equally distributed the value of the world's natural resources, again chiefly because of the moral arbitrariness of their distribution. ${ }^{9}$ Both Joseph Mazor and Steve Vanderheiden have recently defended similar views. ${ }^{10}$ So too, on the basis of a more challenging rendering of the Lockean proviso, have the leftlibertarians Hillel Steiner, Michael Otsuka, and Peter Vallentyne. ${ }^{11}$

But why, from an egalitarian point of view, should we be attracted to the idea of equal natural resource shares? Four possible reasons are assessed in the next section. But showing how each of them fails leaves the field open for the alternative approach defended in the rest of the paper.

III. Arguments for Equal Benefits ${ }^{12}$ 
i) natural resources as the sole currency of equality?

A first argument for equal shares would show that they provided the most appropriate currency for egalitarianism. Insofar as equality appeals to us, what we are troubled by is unequal shares of natural resource benefits; as such by definition it is natural resource benefits - and only natural resource benefits - which we should seek to equalize.

One general way to resist our first argument would be to invoke scepticism about the likelihood that any single metric can be provided for egalitarianism in any case, or, to put it another way, to suggest that insofar as we care about advantage and disadvantage, we are stuck with a conception of advantage which is irreducibly heterogeneous, incorporating a concern with the distribution of both resources and welfare. ${ }^{13}$ Those who are sceptical about resolving the enduring 'currency' problem in such a neat way will be unpersuaded that equal natural resource benefits provide an exhaustively satisfying currency for equality.

But in fact equal benefits should also be rejected by adherents of all of the major currencies. It would command distinctly limited support, for instance, from those who favoured currencies for equality which focused on welfare or capabilities. First, natural resources will 'fuel' the welfare or capabilities of different individuals in uneven ways, so that an individual with a debilitating illness, for instance, may require more resources than another simply to sustain equal levels of welfare or capability. Second, natural resources are not the only significant drivers of welfare or capabilities; thus an individual with hugely marketable abilities may, other things being equal, be able to develop the same capabilities or welfare levels as one of her less lucky fellows even in the presence of glaring inequalities in natural resource 
benefits. It would then be undesirable to insist on equal natural resource benefits in the light of that fact. ${ }^{14}$ Strikingly, a principle of equal benefits would transfer benefits from societies with large shares of natural resources but which are relatively impoverished overall (such as Nigeria), to communities which are on average very wealthy but which enjoy relatively meagre shares of natural resources (like Switzerland). But this would be highly inappropriate if what we were concerned about was overall welfare or capability levels. Even a broad claim that implementing equality of welfare or of capabilities would tend to demand rather more equal shares of natural resources than currently exists would serve us very poorly in many cases. ${ }^{15}$

We might expect advocates of resourcist versions of equality to find the idea of equal natural resource benefits rather more attractive. Ronald Dworkin for instance suggested a vision of equality in which people ought to have an equal ability to obtain the resources which matter to them. But still, even for a defender of equality of resources it would be unjustifiably narrow to insist on equal distribution of (rights over) natural resources in particular. ${ }^{16}$ Stipulating that equality demands only equal natural resource benefits would again appear odd in the light of other inequalities in for instance internal endowments, or in other valued social goods. Once a concern about natural resources is nested within a broader account of egalitarian justice, it is not obvious why inequalities in natural resources might not sometimes be offset by shares of other goods, and vice versa. ${ }^{17}$

A robust version of the claim that natural resources are the solely appropriate distribuenda for an egalitarian theory is defended by Hillel Steiner, but the difficulties his theory faces are instructive. For Steiner, axiomatically, things are either natural resources - in which case we have symmetrical claims over them - or they are the products of labour on which there can be no redistributive claim. In that sense, natural 
resources are the only contender in the search for an appropriate target for redistribution. Importantly, the theory is also intended to enact a choice / circumstance distinction: it is because no-one is responsible for creating natural resources that we all have symmetrical claims over them, whereas the fruits of our own labour - which we are presumably responsible for choosing to exert, or not - are properly considered immune from the redistributive project.

However, Steiner's position faces challenges in insulating distribution from the influence of unchosen circumstance. The first challenge is that of voluntary transfers between individuals. Even with initially equal resource shares, some of us will make more of our natural resources than others, and we might then seek to pass those (legitimate) advantages onto others. Steiner's theory accepts voluntary in-life transfers, and hence cannot eradicate inequalities based upon brute luck. ${ }^{18}$ His theory does seek to block on-death bequests, though, even though these will regularly include artefacts made with human labour (since normally bequests will include things like houses, poetry, or shares in telecommunications companies). In doing so it faces a dilemma. It must either define the content of bequests as natural resources, even though they are the product of (dead) human labour. Or it must depict the currency of justice as natural resources plus the content of any bequests - and therefore relinquish the claim that natural resources are the only appropriate distribuendum for a theory of equality.

A second challenge for Steiner's theory concerns the unequal earning power of the living. Living people are, for Steiner, fully entitled to what they produce with their own labour. But will the theory therefore endorse inequalities based upon varying internal endowments? Steiner accepts that an account which focused exclusively on natural resources conventionally understood would be 'insufficiently 
egalitarian,' in concentrating on 'external' at the expense of 'personal' resources, ${ }^{19}$ but his response is to define internal endowments themselves - or at least, the 'germline genetic information' coded in our DNA - as natural resources on which there is an egalitarian redistributive claim.

My concern, here, is not whether human germ-line information should be considered a natural resource or not. The problem is that even when we include it in the category of natural resources we remain incapable of fully delivering on the choice / circumstance distinction which Steiner claims animates his theory. By way of remedy for the inegalitarian effects of parents' appropriation of germ-line information of varying earning-power, Steiner suggests that we tax the appropriation of genes linked to superior earning power, and compensate those who appropriate genes linked to inferior earning power. ${ }^{20}$ But taxing parents now for the estimated future earning power of their children can hardly prevent children from later benefiting unequally from their unequal talents. At best the taxation of parents will narrow likely inequalities, by making the parents of 'gifted' children poorer on average, and hence less able to pass some of their erstwhile advantages on to their children - as Steiner acknowledges. ${ }^{21}$ Hence the theory's ability to prevent children from benefiting from unequal talents is distinctly limited: as in the case of bequests, even an egalitarian account which defines natural resources very broadly will fail to block inequalities which we have good reason to care about.

ii) the distinctive arbitrariness of natural resource distribution?

A second claim would hold that equal natural resource benefits are demanded because existing benefit shares are arbitrary in a way in which other inequalities are not. If 
existing claims over benefits are especially weak, then perhaps we have a reason for concentrating upon their equalization. That kind of claim is familiar in the global justice literature, but it faces the same challenge as our first claim: if natural resources are not all that matters from the point of view of equality, then why insist on equal benefits?

The response might be that the drive to equalize has a special strength or robustness in the case of natural resources precisely because their currently unequal distribution is a matter of brute luck; as such the egalitarian argument is not dependent on any controversial claims about the genesis of its distribution in human institutions or interactions. Take Charles Beitz's argument by way of example. Beitz famously suggested that a resource redistribution principle could apply even in a counterfactual world of autarkic nation-states. The argument, it might be thought, is especially robust because it does not depend on empirical claims about the effects of globalization, or the emergence of global social cooperation. Unequal resource benefits would require correction even if globalization had not occurred, because it represents a pernicious form of inequality for which its victims (and beneficiaries) cannot be held responsible. $^{22}$

But this position is highly vulnerable. The claim that unequal resource benefits are objectionable whether or not they are produced within the ambit of any global institution or association still fails to identify anything special about natural resources. If the intuition underlying that claim is that arbitrary factors ought not to influence our prospects, then we would surely be led in the direction of a global egalitarian principle which also sought to correct inequalities arising from climate, geography, and also unequal personal endowments. We cannot rule out such possibilities by suggesting that these advantages or disadvantages are not social products and are 
hence inappropriate objects for distribution. Such a response would undercut Beitz's resource redistribution principle too, since he clearly views such resources as not being 'social' products either. We seem to be required to say either that principles of justice apply only to social products (in which case they apparently never apply to natural resources), or to say that they apply to inequalities whether produced by social cooperation or not (in which case singling out natural resources alone for equalization is unjustified).

Even if we accept that they are 'manna from heaven,' then, natural resources do not appear to be the only thing which their holders are not responsible for creating, and over which claims might therefore appear to be weak. Some of us are faced with a situation whereby the particular language we speak enables us to access valuable opportunities more easily. Some of us inherit intellectual property rights from our famous forebears, or fortunes based on singing or playing the violin. We are each of us born into situations of quite multifarious but often likewise unearned advantages and disadvantages, many of which do not have much obvious connection with natural resources, but which are likewise unchosen by their recipients. Once we admit a concern for these other inequalities into our account of justice, the case for opting for equal shares of natural resource benefits in particular disappears.

iii) the distinctive invidiousness of natural resource inequality?

Even if the idea of equal natural resource benefits has very limited appeal when conceived of as an exhaustive account of egalitarian justice, we might still have reason, within a broader egalitarian account, to favour equal shares of natural resource benefits in particular. Even egalitarian accounts concerned with a considerable range 
of goods might still find reason to 'hypothecate' some of them. Hypothecation here refers to the way in which an egalitarian account will select out a good or perhaps several goods and demand (perhaps relatively) equal shares of these goods, regardless of the distribution of other valued goods. In so doing, it will treat some goods as morally incommensurable with other goods, so that advantages or disadvantages 'elsewhere' are not held to compensate for or offset unequal holdings in these specific goods. To give an example, egalitarians might be strongly committed to the political principle of 'one person, one vote.' If so then they would believe that unequal shares of income, say, ought not to be offset by giving extra votes to the poor. Alternatively, they might say that inequalities in access to education ought not to compensated for by giving those thereby deprived greater shares of healthcare. Hypothecating a good suggests that there is a distinctive wrongness about its unequal distribution, which cannot or ought not be offset by shares of other goods.

In many cases we will accept some commensurability between goods: for example, many egalitarians will be content with a society in which some have chosen more leisure, and others more income. But most, on reflection, would not accept complete commensurability between all goods, and indeed I would submit that any plausible egalitarian theory will resist complete commensurability across goods. But why might we see it as inappropriate to use extra votes to offset unequal income, or extra healthcare to offset unequal educational opportunities? One compelling reason for insisting on equal shares of particular goods - which takes us into the domain of non-ideal theory - will apply if we know that inequalities in the distribution of those goods will persistently and invasively lead to inequalities in our holdings of other goods. Perhaps in societies characterised by widespread injustice we know that inequalities in education lead - because it is such a 'positional' good - to pervasive 
inequalities across the whole of economic life. For that reason, we might have especially strong strategic reasons to favour equality in educational provision. ${ }^{23}$ Alternatively, the thought may be that in a society (or world) committed to social equality or equality of status, we will have good reason, at least in some cases, to insist on equality with regards to certain specific goods. ${ }^{24}$ To formulate the principle more defensively, I suggest that we have a reason to hypothecate goods wherever there is a history of inequality of status (such as entrenched gender or ethnic inequality), where that inequality of status is bound up in unequal shares of the good in question, and where hypothecating the good in question appears likely to be successful in breaking that chain of disadvantage. If women, or certain ethnic groups, for example, have been deprived of equal access to certain jobs or colleges (and if, as often happens, their failure to permeate those sectors has served as perverse 'proof' of their inferiority), then we might have strong reasons to seek equal access to those jobs or colleges even if those women or ethnic groups have excellent opportunities elsewhere. A commitment to equal status provides us with a reason to disdain certain inequalities which we would otherwise accept, and the argument for doing so becomes still stronger in the context of profound and ingrained inequalities of status.

Still, even if the egalitarian case for hypothecating some goods is sound, why hypothecate natural resources in particular? It seems plausible that the idea of equality of status can lead us some way in that direction. We know that women have been excluded from property ownership in many countries (including ownership of natural resources), and that these inequalities are bound up, in a complex way, with the view of them as less than full citizens (by which we mean that their inferior access to resources is both a cause, and an effect, of their inequality of status). In such societies addressing gender inequalities might plausibly entail ensuring that women have 
roughly equal access to natural resource benefits. There are also many indigenous communities members of which have been deprived of access to valued natural resources, and been the subject of enduring inequalities of status, with regards to whom the same argument is plausible. In such cases, hypothecating equal natural resource benefits makes egalitarian sense. But it is important to note that this is not an argument for equal shares of natural resources simpliciter. Instead, it is an argument that we sometimes have reasons to favour greater equality of resources in some communities, across certain social groups. Our third possible reason, then, also fails to support equal shares of natural resource benefits across the board.

\section{iv) pragmatic or strategic reasons for equal resource shares?}

A fourth argument (or set of arguments) for equal resource benefits is more pragmatic in character. The claim here is that a policy advocating equal resource benefits enjoys strategic or practical advantages that other egalitarian strategies do not posses. Joseph Mazor, for instance, notes that the drive to equalize holdings in a whole series of social goods presents theories of justice with a set of epistemic difficulties, since that would require us to possess facts about innate capacities, individual choices and so on. By contrast, establishing and then taxing (unequal) holdings of natural resources might be relatively straightforward from the practical point of view. We might also think, along with many economists, that taxing natural resources is relatively efficient (in the sense that it is less prone to producing disincentive effects) than taxing other goods such as income. ${ }^{25}$ Indeed we might even think that taxing natural resources is less likely to interfere with liberty than taxing other social goods. ${ }^{26}$ Finally, we might believe that even if natural resources are not distinctive in their manna-from-heaven 
quality, it might be relatively easy to persuade people to accept taxes on natural resources simply because countervailing claims over them appear to be particularly weak, and that taxes on natural resources are likely to command especially broad philosophical or political support. ${ }^{27}$ In sum, although inequalities in natural resource benefits are not all that matters, they are an area in which progress can relatively easily be made. For all of these reasons, it could be that pursuing equal shares of natural resource benefits represents the most feasible way of making progress towards equality more broadly construed. ${ }^{28}$

Now these various considerations have some force. It may well make sense to prioritise taxes on natural resources, and perhaps it is the case that the incidental costs of doing so (including both financial costs, and costs to liberty) might be more meagre compared with the costs of taxing other goods. However, these considerations offer no support whatsoever to equal natural resource benefits. An egalitarian could agree that there are good practical reasons for prioritising the pursuit of natural resource taxes, and affirm that this is indeed an area in which the chances of success are relatively good. She could even agree that natural resource taxes look especially attractive because of their efficiency and their (relatively small) effects on liberty. But that does not commit us to any particular view on how to disburse the proceeds from such taxes. We could accept all of Mazor's arguments for natural resource taxes and simply say: grant all of the proceeds to the poorest individuals of the world. We could even say, in fact, that it is precisely because it is relatively unlikely that we are going to be able to directly attack other inequalities any time soon that we should use the revenues to ameliorate whichever inequalities concern us the most, rather than restricting our attention to one subset of inequalities that coincide haphazardly at best with overall advantage and disadvantage. In short, even if there are good reasons to 
favour taxes on natural resources as a priority for global justice, this offers no support for the idea of equal benefits.

\section{Natural Resource Benefits and the Demands of Equality}

Section III suggested that a very widespread and simple view about the implications of egalitarianism for the case of natural resources is mistaken. Normatively, there are no good grounds for distributing the benefits arising from natural resources equally. If as egalitarians we ought to care about a whole range of inequalities, a policy aimed at sharing natural resource benefits equally will be defectively egalitarian. Given the poor correlation between natural resource wealth and overall shares of important goods, such a policy would often move funds from people who are, in fact, doing very badly overall in terms of advantage broadly construed, and give them to people who are doing considerably better. Even in cases where natural resource benefits do correlate well with shares in other goods - where those with fewer natural resources are also worse off in other ways - such a policy would still be insufficiently egalitarian, because it would give precisely the same share of natural resource benefits to the rich as it would to the poor of the world. Even if there are good strategic reasons for pursuing the taxation of natural resources, egalitarians ought to reject equal shares of the proceeds.

What can we say positively, then, about the demands of equality with regards to the value of natural resources? First, we will sometimes want to avoid gender and ethnicity-based inequalities in natural resource benefits, especially in societies with a history of exclusion from resource ownership where this exclusion has fed into a vicious cycle of prejudice and stigma. This will provide support for active measures to 
enhance natural resource rights for such marginalised groups. Whilst the approach to equality which I have defended is broadly holist, it does endorse the hypothecation of goods in some circumstances. But whilst there can be reasons to prefer equal natural resource benefits in particular cases, this does not generate an argument for globally equal natural resource benefits.

Second, egalitarians should also seek to (modestly) constrain otherwise unacceptable inequalities by defending a basic entitlement to some essential natural resources. Here we will want to say, roughly, that humans are entitled to sufficient shares of any natural resources which are necessary for them to meet their basic human rights. In making this claim, of course, we reconnect with the tradition of Paine, George and their forebears - many of whom insisted that each person had the right to use the common stock to ensure their subsistence - as well as with some more recent commentators. ${ }^{29}$ Such a principle is capable of commanding broad support; even those with a more modest account of global justice will find reason to object to a world in which many people are deprived of access to resources which are key to human wellbeing. All human beings, simply as human beings, will unavoidably require certain quantities of specific natural resources such as freshwater and clean air. Although it would be perverse to stipulate a universal entitlement to equal shares of freshwater, for instance, it makes sense to secure the basic shares necessary to support basic human rights. ${ }^{30} \mathrm{We}$ ought to specify such a claim whenever specific natural resources serve basic interests in non-substitutable ways.

Securing basic rights in this way will not exhaust the total benefits arising from natural resources. There will remain a large 'surplus' of benefits which may, on some accounts, be vulnerable to taxation in the interests of global justice. Still, even if we accept an egalitarian account of global justice this does not lead inexorably to the 
conclusion that this surplus ought to be distributed evenly. More likely, it ought to be distributed - for egalitarian reasons - with a strong priority towards poor individuals across the world, targeted in such a way as to offset broader inequalities in access to valued social goods. We ought to favour then, third, 'equalizing' rather than equal shares of benefits.

The proceeds of any such taxes are likely to be best used in a variety of ways which have relatively little directly to do with natural resources (including funding progress in dealing with endemic diseases, for instance, or supporting primary education). But in many cases they will also be well spent on major infrastructure projects where the connection to resources is closer, such as projects designed to secure stable and sustainable access to key resources such as clean freshwater, to fund 'technology transfer' schemes to spread green technologies in the developing world, and to fund the protection of natural resources of common concern to all of humankind, such as the rainforests and the polar regions. ${ }^{31}$ This allocation will be informed by a desire to reduce global inequalities and to advance intergenerational justice. But in a world of multifarious advantage and disadvantage we should not assume that the egalitarian impulse can best be met by way of strictly equal shares of benefits.

\section{Limits on Appropriation}

One of the major areas of contestation within discussions of land and natural resources has long been the extent to which given agents are at liberty to appropriate natural resources from common stocks and convert them into private property. It is sometimes suggested in debates about rights over land that this has become an 
essentially historical question. Barring the polar regions we live in a more or less wholly appropriated world; Locke's suggestion that those who do not consent to a particular sovereign could begin their own commonwealths elsewhere has been rendered irrelevant by the virtual demise of terra nullius. What an investigation of limits to appropriation can tell us now, if anything, is how appropriation could have justly occurred, and this might have lessons - though likely not straightforward ones, given the complex facts of history - for present distributions. ${ }^{32}$

But even if the original appropriation of land is of mainly historical interest, appropriation is a live, contemporary and important issue when we switch our attention to natural resources. Apparently unowned natural resources are still being appropriated on a continual basis: individuals collect rainwater for use in drinking, cooking and cleaning, or harness energy from solar radiation to use in domestic heating; corporations are exploring for oil in the deep sea hundreds of miles from the nearest inhabited land; individuals - all individuals - have 'carbon footprints,' by which we mean that they are all, to wildly differing degrees, consuming the ability of the atmosphere or other carbon sinks to absorb greenhouse gases. Meanwhile valuable minerals and fossil fuels are being extracted from under the territories of nation-states, and whereas international law grants nation-states sweeping privileges over 'their' natural resources, at the level of theory their right to do so and to retain the proceeds is a live rather than a settled question. ${ }^{33}$

The question of limits to appropriation is therefore an immensely important one, which drives discussions, for instance, of climate justice. Just how much of the atmosphere's carbon-absorptive capacity can a given agent justly consume? Just how much solar energy, or oil, or wind-power can she remove from common stocks without committing an injustice? Locke's famous answer to that question suggested 
that there was a moral limit to appropriation where appropriation ceased to leave 'enough and as good' for others to appropriate. ${ }^{34}$ That apparently simple claim has been taken up in very different ways, but for many, and influentially, it generates an egalitarian proviso according to which we commit an injustice - and owe compensation, at the very least - when we appropriate more than a symmetrical share of natural resources - or natural resource benefits. However, it is hard to see how such a restrictive egalitarian limit on appropriation can be defended. A necessary move here is to distinguish between a 'narrow egalitarian proviso' and a 'broad' one. A narrow egalitarian proviso places limits on appropriating natural resource benefits in particular, and hence rejects appropriation beyond symmetrical shares even when this might usefully offset other inequalities. A broad egalitarian proviso will allow appropriation beyond symmetrical shares where this usefully forwards equality across the whole range of goods relevant to distributive justice. For instance, a welfarist egalitarian might allow appropriation of benefits for each agent until such a point that their welfare functions become equal; that will place far stricter limits on some agents' appropriation than on others. ${ }^{35}$ A narrow egalitarian proviso, it should be clear, is unduly restrictive, assuming that unequal appropriation might be acceptable - even useful - if it alleviated significant inequalities in the holdings of other goods.

This has important implications for the practice of regulating acquisition, as can be illustrated through the example of climate justice. The principle of equal per capita greenhouse gas emissions enjoys considerable support in discussions of climate justice, and is often taken to be justified on much the same grounds as the purported entitlement to equal natural resource benefits; in the light of the fact that no-one has created the atmosphere's capacity to absorb greenhouse gases, we might ask whether there can ever be good reasons to allow some agents to generate more emissions than 
others. But it is not difficult to provide such reasons. A principle which specifies equal per capita emissions but ignores the scale of the other impacts we make on the carbon cycle (such as, perhaps, protecting or enhancing carbon sinks such as rainforests) is myopic. It is unduly restrictive to focus on one kind of carbon 'debit' alone, to the exclusion of other debits and of possible 'credits' generated by our other activities. ${ }^{36}$ Moreover at the bar of justice a principle of equal per capita emissions is unduly generous to agents who already enjoy greater shares of other important goods, vis-à-vis those whose lives are blighted by poverty, underdevelopment and a general lack of opportunities. This is not to say, of course, that an equal per capita emissions principle would not represent a great advance on the status quo. Likewise there may be strategic considerations which count in favour of equal emissions rights (it might, for instance, be the case that such a principle is more capable of securing lasting agreement than its competitors). But it is far from optimal from the point of view of equality.

\section{Intergenerational Justice}

If we assume that our account of intergenerational justice should be egalitarian, the argument of this paper also has important implications for the question of the shares we should leave behind for future generations. An egalitarian principle of intergenerational justice will demand that we ought not, if we can at all avoid it, impede the ability of future generations to lead lives for which the advantages and disadvantages relevant to distributive justice are as good as those we have enjoyed ourselves. But even assuming such a position, it does not appear to be a requirement of justice that generations across time ought to have equal shares of natural resource 
benefits. That is so for all of the familiar reasons we have rehearsed in previous sections: in contexts of multifaceted, countervailing inequalities, equal natural resource benefits will augment, rather than challenge, the inequalities we ought to care about. But in the case of intergenerational justice, we have additional reasons for resisting equal benefits. Assume, for example, that what we care about is the ability of natural resources to drive access to welfare. That view implies, clearly, that each generation ought to face a world in which any natural resource benefits hold the same potential to fuel welfare. ${ }^{37}$ In the case of the current generation, we have some information - albeit imperfect information - about the role that natural resources play in sustaining the welfare of people across the world. We also have some (rather imperfect) information about other aspects of advantage and disadvantage: we know a lot about global gulfs in life expectancy, in literacy levels, income levels, and so on. When we shift our attention to future generations our information about both of these things becomes radically less secure. We do not know just how future generations will convert natural resource benefits into welfare, and hence just how important such benefits will be to their lives. It might well be that their industries will be radically more efficient than ours, and hence that much smaller shares of benefits will be sufficient to serve their interests equally as well as ours. It is a widespread view that future generations will be much better off than us in financial terms, that they will live longer and healthier lives, and that they will generally benefit from a host of technological advancements unavailable to us. If so, leaving future generations a share of benefits equal to our own appears unnecessary. On the other hand, it may be that we are, through our reckless pursuit of economic growth, consigning future generations to relatively impoverished lives. On such empirical grounds we are irredeemably in the domain of informed conjecture. 
But we are not morally rudderless in our contemplation of intergenerational justice. For one thing, the basic rights constraint should remain in place with regard to future generations. Even if we know little about how natural resources will serve the welfare of future generations, we can be reasonably sure that future generations will be similar enough to us to need clean water, air and so on just as we do. We should therefore leave future generations enough natural resources to meet what can reasonably be foreseen to be their basic rights. This is not to say, to be clear, that we ought to be egalitarian about present generations, and sufficientarian about future generations. The point is the same as for current generations: as global egalitarians, we have scant reason to favour strictly equal resource benefits, assuming that we care about advantage in a suitably broad sense. But we do have good reasons for endorsing a basic rights constraint, and endorsing equalizing shares of benefits. We should apply the same principle in the case of future generations.

For another, even in the face of a good deal of indeterminacy it may be plausible to adhere to some kind of precautionary principle. ${ }^{38}$ It is not baseless conjecture to assert that we are leaving behind us a world in which any future generations will have fewer opportunities than us to interact with wildlife, use nonrenewable energy sources, emit greenhouse gases, and breathe clean air. Even if we cannot know for sure just what their overall levels of advantage will be, it is obvious that many current practices are highly damaging to what we can reasonably expect will be required for decent lives in the future. Moreover, we might well believe that it is wrong if future generations will miss out because of a massive loss of biodiversity, or that we should not unjustly deprive future generations of the ability to lead good lives simply because we are able to consume scarce natural resources without regard to their interests. ${ }^{39}$ 


\section{Conclusion}

In a slogan, the egalitarian's attitude to natural resources should be: tremendously important, but nothing special. Although some accounts have devoted considerable and sometimes exclusive - attention to sharing the benefits they bestow upon us, natural resources truly are not special - in providing a currency for equality, in the arbitrariness of their distribution, in the invidiousness of unequal holdings in them. They are, of course, hugely important to us. But since they are not all that matters, an egalitarian account which grants them their rightful place will not call for equal shares of benefits and burdens. That position, much-beloved though it has been down the history of modern political thought, is not egalitarian enough. The pursuit of equality would be better served by taxing natural resource benefits and distributing the proceeds to advance the interests of the most impoverished. Likewise, insofar as an egalitarian proviso should govern the appropriation of natural resources - whether we think of this as appropriation now, or appropriation vis-à-vis future generations - it should be what I have called a broad egalitarian proviso calling for similarly equalizing - but not equal - shares of benefits. There is likely much to be gained from focusing on natural resources as an entry point for global egalitarian arguments, perhaps because taxes on natural resources would be relatively easy to administer, or relatively likely to command support. Indeed I hope that this is so. But identifying that possible strategic advantage does not provide any direction on how the proceeds of any such taxes should be used. Here the likelihood remains - especially if targeting natural resources is going to be one of the more navigable routes towards global justice - that carefully targeted and equalizing shares of benefits should be our goal. 
${ }^{1}$ Chris Armstrong, 'Resources, Rights and Global Justice: A Reply to Kolers,' Political Studies (2013 forthcoming).

${ }^{2}$ For a fuller defence of that definition, see for example Mathias Risse, On Global Justice (Princeton: Princeton University Press, 2012).

${ }^{3}$ Gerrard Winstanley, 'A Declaration of the Poor Oppressed People of England [1649],' in Christopher Hill (ed) Winstanley: The 'Law of Freedom' and Other Writings (Cambridge: Cambridge University Press, 1983), at p. 97.

${ }^{4}$ John Locke, 'Second Treatise [1690],' in P. Laslett (ed) John Locke: Two Treatises on Government (Cambridge: Cambridge University Press, 1960), pp. 265-428. The precise demandingness of Locke's famous 'proviso' has provoked enduring debate; see for instance Jeremy Waldron, 'Enough and as Good Left for Others,' Philosophical Quarterly 29 (1979): 319-28.

5 Thomas Paine, 'Agrarian Justice [1795],' in M. Foot and I. Kramnik (eds) The Thomas Paine Reader (London: Penguin, 1987), at p.476, 478.

${ }^{6}$ Henry George, Progress and Poverty [1879], (New York: Cosimo: 2005).

${ }^{7}$ Charles Beitz, Political Theory and International Relations (Princeton: Princeton University Press, 1979).

${ }^{8}$ Beitz later suggested that he rather regretted foregrounding resource inequalities so much, but still, intriguingly, held out the possibility that a principle of equal entitlement to natural resources could play a useful role in a broader egalitarian account. Charles Beitz, 'Reflections,' Review of International Studies 31.4 (2005): 409-23.

${ }^{9}$ Brian Barry, 'Humanity and Justice in Global Perspective,' Nomos XXIV: Ethics, Economics and the Law (1982): 219-52; see also his 'Do Countries Have Moral Obligations? The Case of World Poverty,' in Sterling McMurrin (ed) The Tanner Lectures on Human Values, Volume 2 (Cambridge: Cambridge University Press, 1981), pp. 25-44.

${ }^{10}$ Joseph Mazor, 'Liberal Justice, Future People and Natural Resource Conservation,' Philosophy and Public Affairs 38.4 (2010): 380-408; Steve Vanderheiden, Atmospheric Justice (Oxford: Oxford University Press, 2009).

${ }^{11}$ Hillel Steiner, 'Territorial Justice and Global Redistribution,' in G. Brock and H. Brighouse (eds) The Political Philosophy of Cosmopolitanism (Cambridge: Cambridge University Press, 2005), pp. 2838; Otsuka, Steiner and Vallentyne, 'Why Left-Libertarianism is not Incoherent, Indeterminate, or Irrelevant," Philosophy and Public Affairs 33 (2005): 201-15.

${ }^{12}$ In a superb recent paper, Simon Caney has critically assessed several arguments in favour of equal rights to emit greenhouse gases. See Caney, 'Just Emissions,' Philosophy and Public Affairs 40.4 (2012): 255-300. Although his focus is not on shares of natural resources more broadly, as mine is, the 
arguments he canvasses overlap to a degree with some of those assessed in Section III here. But only partly, and insofar as I identify some distinct arguments our papers can be seen as providing complementary routes towards similar conclusions.

${ }^{13}$ See G. A. Cohen, 'Afterword to Chapters 1 and 2,' in Michael Otsuka (ed) G. A. Cohen: On the Currency of Egalitarian Justice, and Other Essays in Political Philosophy (Princeton: Princeton University Press, 2011), pp. 61-72.

${ }^{14}$ The second objection, we could say, suggests that equal natural resource shares is only part of what egalitarians want, whereas the first suggests that in this respect equal natural resource shares would be contrary to what egalitarians ought to want more broadly. Both objections remain in play in this section. ${ }^{15}$ See Michael Otsuka, 'Self-Ownership and Equality: A Lockean Reconciliation,' Philosophy and Public Affairs 27.1 (1998): 65-92. Cf. Richard Arneson, 'Liberal Egalitarianism and World Resource Distribution: Two Views,' Journal of Value Inquiry 23 (1989): 171-90.

${ }^{16}$ Thus whilst Dworkin's own hypothetical auction does focus on achieving envy-freedom in the distribution of natural resources, he ultimately augments that position with a hypothetical insurance market designed to achieve envy-freedom in a much broader class of resources, including internal endowments. See Dworkin, Sovereign Virtue (London: Harvard University Press, 2000).

${ }^{17}$ I say sometimes because, as I show in III.iii, there are moral limits to such offsetting.

${ }^{18}$ Michael Otsuka, 'Owning Persons, Places and Things,' in S. de Wijze, H. Kramer and I. Carter (eds) Hillel Steiner and The Anatomy of Justice (London: Routledge 2009), pp. 132-44.

${ }^{19}$ Hillel Steiner, 'Sharing Mother Nature's Gifts: A Reply to Quong and Miller,' Journal of Political Philosophy 19.1 (2011): 110-23, at 112.

${ }^{20}$ Steiner, An Essay on Rights (Oxford: Blackwell, 1994), p. 279.

${ }^{21}$ Ibid., p. 280.

${ }^{22}$ Beitz, Political Theory, p. 137. Though he actually rejects equal shares, a similar thought about the special non-created nature of natural resources appears to animate Risse's claim that they generate a specific 'ground of justice,' entailing specific and separate distributive constraints. See Risse, On Global Justice, Part 2. The doubts I express about Beitz's view in this sub-section would also apply to Risse's.

${ }^{23}$ See Harry Brighouse and Adam Swift, 'Equality, Priority and Positional Goods,' Ethics 116 (2006): 471-97.

${ }^{24}$ This is what Caney calls the 'equal rights' argument. See Caney, 'Just Emissions,' at 273-4.

25 Joseph Mazor, A Liberal Theory of Natural Resource Property Rights, PhD thesis, Harvard University (2009), p. 119, p.121. Paula Casal cites as an advantage of natural resource taxes the relatively low likelihood that they will disincentivise productive activites. Casal, 'Global Taxes on Natural Resources,' Journal of Moral Philosophy 8.4 (2011): 307-327, at 312.

${ }^{26}$ Mazor, A Liberal Theory, p. 127.

${ }^{27}$ Casal, 'Global Taxes,' at 312.

${ }^{28}$ Mazor, A Liberal Theory, p. 134. 
${ }^{29}$ A similar idea has been embraced, famously, by Thomas Pogge, World Poverty and Human Rights. It is also suggested as a constraint on tolerable inequalities in resource shares by Risse, On Global Justice.

${ }^{30}$ See e.g. Peter Gleick, 'The Human Right to Water,' Water Policy 1.4 (1998): 487-503.

${ }^{31}$ On which see Chris Armstrong, 'Sharing the Costs of Rainforest Protection,' ms.

${ }^{32}$ Cohen, for instance, suggests that Locke's account 'fails to justify private property in the real and fully appropriated world,' Self-Ownership, Freedom and Equality (Cambridge: Cambridge University Press, 1995), at p. 188. On the complexities of drawing lessons from historical wrongdoing, see Jeremy Waldron, 'Superseding Historic Injustice,' Ethics 103.1 (1998): 4-28.

${ }^{33}$ See Chris Armstrong, 'Against "Permanent Sovereignty" over Natural Resources,' Politics, Philosophy and Economics (forthcoming 2014).

${ }^{34}$ On Waldron's interpretation, note, Locke's argument does not so much provide a full account of moral limits to appropriation, but rather illustrate a set of cases where there could be no reasonable objection to appropriation. Waldron, 'Enough and As Good Left for Others.'

${ }^{35}$ See for instance Michael Otsuka's defence of a principle according to which 'those who are, through not fault of theirs, less able to convert worldly resources into welfare are entitled to acquire additional resources in order to compensate for this lesser ability.' Otsuka, 'Self-Ownership and Equality,' at 81.

${ }^{36}$ See Caney, 'Just Emissions.'

${ }^{37} \mathrm{Cf}$. Otsuka, who appears to assume such a principle demands 'a world of unowned resources that is undiminished when compared with that which faced the previous generation.' Otsuka, 'Self-Ownership and Equality,' at 89-90. What Otsuka's position should demand is a world in which the potential of resources to fuel welfare is undiminished - but if we have reason to expect the ability of resources to fuel welfare to vary over time (see below), the actual required stock of resources should be expected to vary accordingly.

${ }^{38}$ For a careful defence of a precautionary principle in the context of climate change, see Stephen Gardiner, 'A Core Precautionary Principle,' Journal of Political Philosophy 14.1 (2006): 33-60.

${ }^{39}$ We may well have further reasons, of course, to restrain our consumption of scarce resources, and indeed positively to protect many of them. We might believe that some natural resources have intrinsic value, though that does not lead directly to an argument for their conservation. See John O’Neill, 'The Varieties of Intrinsic Value,' The Monist 75.2 (1992): 119-37. 